University of Wollongong

Research Online

Faculty of Law, Humanities and the Arts Papers (Archive)

Faculty of Arts, Social Sciences \& Humanities

$1-1-2014$

UNHCR as a Subsidiary Organ of the UN: Plurality, Complexity and Accountability

Niamh H. Kinchin

University of Wollongong, nkinchin@uow.edu.au

Follow this and additional works at: https://ro.uow.edu.au/lhapapers

Part of the Arts and Humanities Commons, and the Law Commons

Research Online is the open access institutional repository for the University of Wollongong. For further information contact the UOW Library: research-pubs@uow.edu.au 


\title{
UNHCR as a Subsidiary Organ of the UN: Plurality, Complexity and Accountability
}

\begin{abstract}
The global space is a place where decision-making and regulation involve diverse actors who act outside of State control yet who affect the rights and obligations of individuals and groups. Its innate plurality speaks against the temptation to understand accountability as a predetermined concept. Instead, it is argued that accountability within the global context should be reconceptualised through the relationships of global decision-making bodies. The United Nations High Commissioner for Refugees (UNHCR) is a subsidiary organ of the UN. If an enquiry into what UNHCR is accountable for is undertaken through an examination of its relationship with the UN according to a type of accountability, rather than as a measurable outcome of externally imposed, uniform "accountability standards", divergent and potentially conflicting accountability obligations will be revealed. As discussed in this paper, when the relationship between UNHCR and the UN is considered through legal accountability, it becomes evident that the position of UNHCR as a subsidiary organ allows the UN to retain a degree of control and supervision over UNHCR that corresponds with its functional autonomy, and that the terms of UNHCR's Statue determines the scope of that control and supervision. When considered through organisational accountability, however, complex considerations involving hierarchy, "unspoken authority", political influence and horizontal accountability become evident. An understanding of the layered nature of the relationships of UNHCR creates a clearer perception of the body's accountability, and the relationship between the UN and UNHCR, which is also represented by a conceptual model, provides insight into the limits of what UNHCR can and cannot achieve as part of its mandate, and in its wider role as a humanitarian agency. It is only when the nature of a global decision-making body's accountability relationships are understood that the expectations, or accountability obligations, that flow from them will emerge. To identify what a global decision-making body is accountable for before identifying its relationships may create expectations of accountability that do not relate to the body's operations or relationships, and will produce skewed results of its accountability performance, potentially impeding the development of effective and relevant accountability mechanisms.
\end{abstract}

\section{Keywords}

un, plurality, organ, complexity, unhcr, accountability, subsidiary

Disciplines

Arts and Humanities | Law

\section{Publication Details}

N. H. Kinchin, 'UNHCR as a Subsidiary Organ of the UN: Plurality, Complexity and Accountability' (Paper presented at the IRPA Working Paper GAL Series n. 4/2013, Viterbo, Italy, 13-14 June 2013). 2014 


\title{
I R P A
}

ISTITUTO DI RICERCHE

SULLA PUBBLICA AMMINISTRAZIONE

GLOBALADMINISTRATIVE LAW

WORKING PAPERS

\section{UNHCR as a Subsidiary Organ of the UN: Plurality, Complexity and Accountability}

\author{
NIAMH KINCHIN \\ PhD candidate, University of New South Wales \\ Master of Administrative Law and Policy (MALP), University of Sydney \\ Bachelor of Laws (LLB) (Hons Class 1), University of Western Sydney \\ Bachelor of Social Science (BSSc), University of Newcastle \\ Sessional Lecturer, University of Wollongong
}

IRPA Working Paper - GAL Series No. 4/2013 
All rights reserved.

No part of this paper may be reproduced in any form

without permission of the author.

Copy editor: Martina de Lucia

(C) 2014 NIAMH KINCHIN

Istituto di Ricerche sulla Pubblica Amministrazione

00199, Rome, Italy

www.irpa.eu

IRPA Working Papers - ISSN 2280-868X

Cite as:

N. Kinchin, "UNHCR as a Subsidiary Organ of the UN: Plurality, Complexity and Accountability", IRPA Working Paper GAL Series n. 4/2013 Finalized 11/20/2013

(www.irpa.eu).

The IRPA - Istituto di ricerche sulla pubblica amministrazione (Institute for research on public administration) is a non profit organization, founded in 2004 by Sabino Cassese and other professors of administrative law, which promotes advanced studies and research in the fields of public law and public administration. The current president is Prof. Luisa Torchia.

Global Administrative Law Steering Committee:

Professors Stefano Battini, Lorenzo Casini, Edoardo Chiti, Mario Savino, Giulio Vesperini.

IRPA Working Papers Steering Committee:

Professors Stefano Battini, Sabino Cassese, Lorenzo Casini, Edoardo Chiti, Bernardo Giorgio Mattarella, Giulio Napolitano, Aldo Sandulli, Mario Savino, Luisa Torchia, Giulio Vesperini. 


\title{
UNHCR as a Subsidiary Organ of the UN: Plurality, Complexity and Accountability
}

\author{
Niamh Kinchin ${ }^{1}$
}

\begin{abstract}
The global space is a place where decision-making and regulation involve diverse actors who act outside of State control yet who affect the rights and obligations of individuals and groups. Its innate plurality speaks against the temptation to understand accountability as a predetermined concept. Instead, it is argued that accountability within the global context should be reconceptualised through the relationships of global decision-making bodies.

The United Nations High Commissioner for Refugees (UNHCR) is a subsidiary organ of the UN. If an enquiry into what UNHCR is accountable for is undertaken through an examination of its relationship with the UN according to a type of accountability, rather than as a measurable outcome of externally imposed, uniform "accountability standards", divergent and potentially conflicting accountability obligations will be revealed. As discussed in this paper, when the relationship between UNHCR and the UN is considered through legal accountability, it becomes evident that the position of UNHCR as a subsidiary organ allows the UN to retain a degree of control and supervision over UNHCR that corresponds with its functional autonomy, and that the terms of UNHCR's Statue determines the scope of that control and supervision. When considered through organisational accountability, however, complex considerations involving hierarchy, "unspoken authority", political influence and horizontal accountability become evident.

An understanding of the layered nature of the relationships of UNHCR creates a clearer perception of the body's accountability, and the relationship between the UN and UNHCR, which is also represented by a conceptual model, provides insight into the limits of what UNHCR can and cannot achieve as part of its mandate, and in its wider role as a humanitarian agency. It is only when the nature

\footnotetext{
${ }^{1}$ The Author is a PhD candidate at the University of New South Wales. Her research interests include Global Administrative Law, public law and the intersection of international and domestic law. Her current research considers accountability within the global space in the context of international refugee law, with particular focus on the United Nations High Commissioner for Refugees.

Niamh Kinchin is a qualified lawyer with a background and interest in Australian public law. She holds a Master of Administrative Law and Policy from the University of Sydney and was previously employed at the Commonwealth Administrative Appeals Tribunal, Australia's peak administrative tribunal. She currently teaches Administrative Law, Constitutional Law and Torts at the University of Wollongong. Adress: 38 Bulbi Street, Pemulwuy, NSW Australia, 2145.
} 
of a global decision-making body's accountability relationships are understood that the expectations, or accountability obligations, that flow from them will emerge. To identify what a global decision-making body is accountable for before identifying its relationships may create expectations of accountability that do not relate to the body's operations or relationships, and will produce skewed results of its accountability performance, potentially impeding the development of effective and relevant accountability mechanisms.

Keywords. Accountability, UNHCR, UN, Subsidiary organ, Relationships, Obligations, Standards, Indicators, Inter-Institutional, Global governance 
Beyond the traditional boundaries of sovereignty and international law exists the global space. A forum for global or transnational administration, ${ }^{2}$ where decision-making and regulation involve diverse actors who largely act outside of State control, yet who affect the rights and obligations of individuals and groups, it is a context whose scope defies identifiable parameters. If there is a legal order, it is fragmented. If there is a constituency, it is a fractured one. The conditions for an accountability deficit are there, and if accountability solutions are to be effective the innate plurality of the global space must be acknowledged in a way that recognises that accountability cannot be defined through preconceptions of what that concept should entail. An examination of the inter-institutional relationships of the United Nations High Commissioner for Refugees (UNHCR), demonstrates that when accountability is understood as a product of the relationships of a global decision-making body ("global body"), it becomes responsive to the unique challenges and obligations of that body, as well as to the way that external principles such as international law or human rights impact it. If what a global decision-making body is accountable for is identified before its relationships, there is a risk of the creation of expectations of accountability that may not relate to that body's functions and purpose. It is the relationships of global bodies that produce its accountability obligations and an appreciation of those obligations, including how they intersect and conflict with each other, is crucial to the successful design and implementation of effective and responsive accountability mechanisms.

UNHCR is a special programme and subsidiary organ of the United Nations (UN). If an enquiry into what UNHCR is accountable for is undertaken through an examination of its relationship with the UN according to a 'type' of accountability, rather than as a measurable outcome of externally imposed uniform "accountability standards", then divergent and potentially conflicting accountability obligations will emerge, When the relationship between UNHCR and the UN is considered through legal accountability it becomes evident that the position of UNHCR as a subsidiary organ allows the UN to retain a degree of control and supervision over UNHCR that corresponds with its functional autonomy $^{3}$ and that the terms of UNHCR's Statue ${ }^{4}$ determines the scope of that control and supervision. Yet this is an incomplete picture of UNHCR's accountability obligations. UNHCR's relationship with the UN can also be considered through organisational accountability, which introduces complex considerations involving hierarchy, "unspoken authority", political influence and horizontal accountability. An understanding of the layered nature of the relationships of UNHCR creates a clearer perception of the body's accountability, and the relationship between the UN and UNHCR provides insight into the limits

2 B. Kingsbury, N. Krisch and R. B Stewart, "The Emergence of Global Administrative Law" 68 (3-4) Law and Contemporary Problems (2005) p. 16.

3 International Law Association, Third Report Consolidated, Revised and Enlarged Version of Recommended Rules and Practices (RRP's) New Dehli Conference 2002, 6 (ILA Report).

4 Resolution on Statute of the High Commissioner for Refugees, GA Res 428(V) UN GAOR, $5^{\text {th }}$ sess, $325^{\text {th }}$ plen mtg, Doc/A/Res/428(v) (1950). 
of what UNHCR can and cannot achieve as part of its mandate, and in its wider role as a humanitarian agency.

\section{A Plural Approach to Accountability in the Global Space}

In the search for a solution to the accountability deficit in the global space, the diversity of that context should not be overlooked in favour of an approach that limits the ability of accountability to respond to plurality. When the requirements for accountability are standardised, or applied in a uniform way that fails to consider the unique characteristics of the context in which they operate, or are not divorced from the assumptions that inform them, the potential for creating effective accountability solutions is threatened.

One way accountability is standardised is through the use of indicators. Indicators are used to compare a variety of social and socio-political phenomena such as corruption, ${ }^{5}$ the rule of law ${ }^{6}$ and human trafficking ${ }^{7}$ in relation to countries, institutions or corporations, and evaluate their performance by reference to one or more standards. ${ }^{8}$ When indicators are used to "measure" accountability they tend to cast adrift substantive issues in favour of the kind of procedural standards that are generally considered to be components of accountable governance, such as transparency and participation. For example, One World Trust is a London-based independent charity that produces research on accountability and global governance. Its Global Accountability Framework (GAF) develops an indicator framework that is designed to measure the accountability of intergovernmental organisations, transnational corporations and international non-governmental organisations. " GAF "unpacks" accountability into what it calls "dimensions", which are transparency, participation, self-evaluation and "complaint and response". ${ }^{10}$ These dimensions are further separated into indicators, ${ }^{11}$ each of which has levels ${ }^{12}$ that are scored from $0-3$ according to a scaled system.

The difficulty with such procedural indicators is that when are separated from substantive content, they risk losing their relevance. Indicators that measure

\footnotetext{
5 Transparency International, a global civil society organisation, produces an annual Corruption Perception Index.

6 In 2002, UNDP developed a Political Freedom Index, which included "rule of law" as an indicator.

$7 \quad$ Trafficking in Persons indicators have been produced by the US State Department.

K.E. Davis, B. Kingsbury and S.E. Merry, "Indicators as a Technology of Global Governance" 46 Law and Society Review (2012) p. 71.

$9 \quad$ Pathways to Accountability II: The 2011 Revised Global Accountability Framework (2011) ('2011 GAF Report') One World Trust <http://oneworldtrust.org/publications/cat_view/64publications-by-project/69-principles-of-accountability> p. 18.

$10 \quad$ Ibid 55.

11 Accountability strategy, transparency, participation - external stakeholders, participation - internal member control/good governance, participation - shareholder control/good governance, evaluation (IGOs and INGOs), social and environmental evaluation (TNCs), complaints and response - external and complaints and response - internal. 2011 GAF Report, p. 31.

12 For example the indicator "Accountability Strategy" is broken into the following three levels: 1) Stakeholder mapping and prioritization; 2) Accountability mapping and action plan; 3) Commitment to and awareness of existing external accountability commitments.
} 
substantive issues, such as the quality of business laws and institutions ${ }^{13}$ or social and economic development ${ }^{14}$ do so based upon collective knowledge, experience and expertise. The World Bank's Doing Business indicators measure regulatory output in relation to dealing with construction permits, getting electricity, registering property, getting credit, protecting investors, paying taxes, trading across borders, enforcing contracts, closing a business and employing workers. ${ }^{15}$ These indicators are understood to represent substantive elements that are common to all business regulation. Indicators that are used to measure accountability of governance consider procedural issues, which is relatively unproblematic in the domestic context because there is a somewhat cohesive understanding of governance that bonds procedural accountability to substantive governance elements. For example, the democratic legitimacy that underpins many of the world's governance structures has influenced the development of procedural rights, such as natural justice or "procedural fairness". However, in the global context, governance methodology is disparate, making it difficult to "pin" accountability indicators on concrete and measurable outcomes, which then encourages a tendency to frame accountability according to the commentator's experiences of domestic socio-political and legal traditions.

Commentators and decision makers from common law countries may find it difficult to divorce their notion of accountability from responsible government and the institutional checks and balances that uphold it. ${ }^{16}$ Commentators and decision makers from civil law countries will tend to understand the "adjudication of accountability" (i.e. administrative and judicial review) to require a high level of involvement by judges in evidence collection and policy making, and an inquisitorial participation in the decision-making process. ${ }^{17}$ Whilst experience of pre-existing domestic accountability mechanisms serve as an important tool in the institutional design of accountability mechanisms in the global space, a failure to identify underlying assumptions may result in an incongruence that will be counter-productive to designing and implementing effective solutions to the global accountability deficit.

A second challenge posed by the use of procedural accountability indicators in the global space is that their purpose may be subverted in order to legitimise the actions of an organisation. One function of indicators is standard setting. ${ }^{18}$

13 Such as the "Doing Business" indicators, which are utilised by the World Bank. See K.E. Davis, B. Kingsbury and S.E. Merry, "Indicators as a Technology of Global Governance" 46 Law and Society Review (2012) pp.90-95.

14 See Davis, Kingsbury and Merry's discussion of the Human Development Index. Ibid pp. 95-99.

15 Doing Business 2013: Smarter Regulations for Small and Medium-Size Enterprises World Bank <publications.worldbank.org/index.php?main_page=product_info\&products_id=24391 > visited 15 October 2013.

16 See generally P. Finn, "Public Trust and Public Accountability" 3 Griffith Law Review (1994) pp. 224-244; J. Goldring, "Accountability of Commonwealth Statutory Authorities and "Responsible Government" 11 Federal Law Review (1980) pp. 353-385.

17 See B. Schwartz, French Administrative Law and the Common Law World (The Law Book Exchange, New Jersey, 2006) pp. 132-135.

${ }_{18}$ K.E. Davis, B. Kingsbury and S.E. Merry, "Indicators as a Technology of Global 
Externally imposed indicators act as a guide to "community values" and will serve as a useful tool with which to design an organisation's standards. For example, transparency, which it can be argued is a fundamental expectation within a democratic community, may be transformed into a procedural standard that requires policy documents to be published on an Internet database within a certain amount of time. Although the prospect of community values shaping organisational behaviour in a practical way is undoubtedly positive, where indicators are used as a way to create standards that justify "actions to those whom they affect according to reasons they can accept" ${ }^{\prime \prime}$ rather than reflect the actual accountability obligations that arise from an organisation's relationships, the result may be reduced to an exercise of self-legitimisation.

When accountability in the global space is examined in terms of legal accountability, ${ }^{20}$ an absence of a cohesive legal order becomes apparent. No one legal order can claim exclusivity of the global space and although it is not a lawless frontier by any means, the contribution of many and varied domestic legal systems, along with the presence of international law, leaves a global legal order that is fragmented, at best. It follows that without a unified legal ontology the concept of accountability is vulnerable to being populated by assumptions about its normative content. For example, calls for democracy at the global level have been accompanied by claims that a fundamental function of accountability is to achieve democratic aims. In her examination of the accountability of government networks, Anne-Marie Slaughter acknowledges that accountability is a complex concept that can mean different things in different contexts and according to "different political theories". ${ }^{21}$ At the same time however, she claims that "determining how to hold these officials" (in relation to officials of networks of government agencies) democratically accountable becomes a paramount concern. ${ }^{22}$ The influence of differing political theories is acknowledged, yet the connection between democracy and accountability is assumed. A presumption that democracy and accountability are inextricable may result in a failure to consider the challenge of how accountability might adapt to spaces (global or national) where there is no democracy, as we understand it in its traditional sense. ${ }^{23}$

Human rights also provide discourse that is a strong normative basis for much of the commentary on global accountability ${ }^{24}$ and is increasingly presumed to

Governance" 46 Law and Society Review (2012) p. 83.

19 M.D. Williams, "Citizenship as Agency within Communities of Shared Fate" in S. Bernstein and W.D. Coleman (eds.), Unsettled Legitimacy: Political Community, Power, and Authority in a Global Era (University of British Columbia Press, Vancouver, 2009) p. 43.

20 According to R.W. Grant and R.O. Keohane, legal accountability "refers to the requirement that agents abide by formal rules and be prepared to justify their actions in those terms, in courts or quasi-judicial arenas». See R.W. Grant and R.O. Keohane, "Accountability and Abuses of Power in World Politics" 99 American Political Science Review (2005) p. 17.

21 A-M. Slaughter, "The Accountability of Government Networks" Indiana Journal of Global Legal Studies 8 (2000-2001) p. 360.

$22 \quad$ Ibid 348 (emphasis added).

23 «Even in a bare monarchical legal order in which there is administrative law, one assumes that there is accountability to the law of the state». See D. Dyzenhaus, "The Concept of (Global) Administrative Law" Acta Juridica (2009) p. 6.

$24 \quad$ See e.g., M. Lion, "Human Rights Obligations and Accountability in the Face of Climate 
underpin the policy design and implementation of International Organisations (IO) and the UN and its agencies. Measuring how accountable a body or agency is for the "protection of human rights" 25 without a corresponding requirement to qualify who they are owed to and what they are owed for, risks human rights accountability becoming a noble but ultimately superficial goal. Human rights of individuals within the context of administrative decision-making are often understood as meaning procedural rights, such as transparency, participation and due process. However, procedural rights may be of limited relevance to a global body whose decisions do not affect individuals directly. Without adapting human rights accountability to a specific context and to a specific body, the implementation of human rights protection into policy and programme design will be of limited effect.

Another assumption about accountability in the global space is that it is based on public values. However, hybrid public-private and wholly private organisations that are also global bodies are not totally receptive to the imposition of the public values that tend to inform accountability. In the former, both government representatives and private parties play a role in policy design and decisionmaking. To impose expectations of accountability that are modelled upon public or "citizen" participation and transparency may fail to recognise the competing interests of the private participants in the organisation. Wholly private organisations have no governmental representatives and therefore no particular responsibility to include transparency and participation in its platform that stems from a sense of public or political accountability. Measuring or ranking such global bodies based upon transparency in the same way as an IO will say little about their platform, stakeholders and relationships and creates straw man standards in the guise of legitimate expectations of accountability.

Whether through indicators that purport to measure the accountability of governance, or through assumptions about what accountability means, when accountability is applied to the global space in a way that fails to recognise the complexity and plurality of that context, the potential for effective solutions is compromised. Identification of a recipient of accountability within the global space is a more layered and complex process than within the domestic context. Citizen rights and relationships with government at the national level are commonly described according to political accountability because a clear relationship exists between the government and the "people". In the global space, a fractured constituency may exist but a global demos does not, and as such, the identity of the recipients of accountability are not immediately clear. If there is a global constituency, it is made up of interlacing but competing "sub-

Change" 38 Georgia Journal of International and Comparative Law (2010) p. 543; M. Pallis, "The Operation of UNHCR's Accountability Mechanisms" 37 International Law and Politics (2005) pp. 869 and 874.

25 See e.g., J. Wouters, E. Brems, S. Smis, P. Scmitt (eds) Accountability for Human Rights Violations by International Organisations (Intersentia, Cambridge, 2010); J. M. Woods, "A Human Rights Framework for Corporate Accountability" 17 ISLA Journal of International and Comparative Law (2011) pp. 321-334; A. Buchanan \& R. O. Keohane, "The Legitimacy of Global Governance Institutions" 20 Ethics \& International Affairs p. 406. 
constituencies", which vie for influence in global governance. ${ }^{26}$ Understanding accountability at the global level requires re-evaluation of the concept of political accountability to accommodate uncertainty about who it is that global bodies are accountable to.

Accountability that is limited to pre-conceived standards is not designed to sufficiently respond to plurality, which is one of the defining characteristics of the global space. Whilst indicators in particular can demonstrate, in a public and practical way, how States and global organisations may be "held to account", it is questionable whether the concept of global accountability is cohesive enough, or whether global bodies are sufficiently similar to render a standardised or assumed understanding of accountability effective within this context.

\section{Accountability through the Looking Glass: How UNHCR's Institutional Relationships Shape its Accountability Obligations}

If accountability is to be "achieved" in the global space, it must be understood in terms of relationships. It is only when the nature of a global body's relationships are understood that the expectations that flow from them will emerge. The nature of a global body's relationships depends upon the unique nature, objectives and structure of that body. The expectations that flow from a body's relationships are accountability obligations, which describe what a global body is accountable for, based upon its relationships. Accountability obligations are not autonomous; they intersect, compete with and undermine each other. Understanding the way that accountability obligations intersect reveals why a body is not accountable in some way. Understanding accountability as relationships reflects the fundamental diversity of the global space and is in contrast to a more traditional method that defines accountability according to external standards (discussed above) and is imposed according to whom the body believes itself to be accountable. ${ }^{27}$ The consequence of a "relationship approach" to accountability is that the impact of the type of accountability (e.g., legal and political accountability) is not considered until after a global body's relationships have been identified.

Applying this approach to explore UNHCR's accountability involves identification of its relationships and asking what accountability obligations arise from that relationship, based upon a particular type of accountability. This paper focuses upon UNHCR's inter-institutional relationship with the UN, and poses the question, "what accountability obligations arise when this relationship is considered through legal and organisational accountability"? The answer reveals that UNHCR's accountability obligations compete with and undermine each

26 N. Krisch, "The Pluralism of Global Administrative Law" 17(1) European Journal of International Law (2006) p. 247, p. 253. Krisch identifies three possible approaches to identifying constituencies in the global space; nationalist, internationalist and cosmopolitan.

27 According to Kingsbury, a public entity may be accountable to its public, «yet the decision may be taken by an entity whose public is not the public truly affected». See B. Kingsbury, "The Concept of 'Law' in Global Administrative Law", Working Paper No 2009/1, Institute for International Law and Justice, NYU, (2009) p. 42. 
other, and are more complex than a standardised or uniform understanding of accountability could hope to accommodate.

\subsection{UNHCR's Relationship with the UN: Legal Accountability}

The relationship that exists between UNHCR and the UN can be described as vertical in the sense that it is shaped by UNHCR's position as a subsidiary organ and is dictated by the express words of UNHCR's Statute. However, the limited terms of UNHCR's Statute, coupled with expectations of UNHCR's independence, define that relationship in such a way as to limit the practical control that the UN, in the guise of the UN General Assembly (UNGA) and ECOSOC, exercises over UNHCR.

Whilst the relevant parts of the UN Charter and the general law that governs international institutions dictate the establishment and termination of subsidiary organs, the power of the subsidiary organ to make decisions is determined by the limits of its own mandate ${ }^{28}$ For a subsidiary organ to be lawfully established, two pre-conditions must be met. First, it must be established by a principal organ ${ }^{29}$ and second, it must be under the authority and control of that principal organ. ${ }^{30}$ The parameters of authority and control are not defined by the UN Charter but have been variously described as the ability of the principal organ to change the terms of reference and composition of the subsidiary organ, issue policy directives, receive reports from the subsidiary organ, accept or reject their recommendations, ${ }^{31}$ overrule a decision by a subsidiary organ if that decision is contrary to applicable legal rules and the right to question the way in which the subsidiary organ has exercised its competence. ${ }^{32}$ Regardless of how the authority of the principal organ is defined, it does not extend to dictation of the way that the subsidiary organ carries out its functions or makes its decisions, the lawfulness of which is contingent on whether such actions are vires the subsidiary organ's mandate. In practice, the degree of control and supervision a principal organ has over the subsidiary organ is determined not by elusive principles of authority but by the terms of its mandate and its functional autonomy. ${ }^{33}$

The terms of UNHCR's mandate that are relevant to the authority and control of the UN and thus, which create accountability obligations for UNHCR, are Paragraphs 3, 9 and 11 of its statute. Paragraph 3 of UNHCR's Statute requires the High Commissioner "to follow policy directives given him by the General

\footnotetext{
$28 \quad$ Ibid 86.

29 Charter of the United Nations, art 7(2)

30 A subsidiary organ has been defined by the UN as one that is established by or under the authority of a principal organ. General Assembly Official Records, 9th Session, Annexes, Agenda Item 67, at p. 13, A/C 1/758, paras. 1 and 2. Repertory of Practice of United Nations Organs, vol. 1, p. 228.

General Assembly Official Records, 9th Session, Annexes, Agenda Item 67, at p. 13, A/C 1/758, paras. 1 and 2. ILA Report, 5. See also Repertory of Practice of United Nations Organs, vol. I, p. 228.

33 Ibid.
} 
Assembly or the Economic and Social Council". ${ }^{34}$ Paragraph 9 gives the UNGA authority to determine additional activities. ${ }^{35}$ Although the UNGA does not specify which of its resolutions deal with "policy" and which determine "additional activities", they may be best differentiated by characterising the former as an elaboration of UNHCR's activities related to its mandated responsibilities and the latter as the intention to add new responsibilities. ${ }^{36}$ In practice, Paragraph 3 and 9 translate to the annual adoption of "omnibus" resolutions, which clarify the UNGA's concerns and priorities about displacement on a global basis and "situational" resolutions, which refer to specific countries. ${ }^{37}$ Finally, Paragraph 11 requires UNHCR to report annually to the UNGA through the Economic and Social Council (ECOSOC). ${ }^{38}$

UNHCR's relationship with ECOSOC, which is a body internal to the UN that was established to coordinate the work of its 14 specialised agencies, ${ }^{39}$ is not built upon the same level of authority/subordination as its relationship with UNGA. As mentioned above, Paragraph 11 of UNHCR's statute declares that UNHCR is to report to the UNGA through ECOSOC. In practice, UNHCR now submits its annual reports to the UNGA directly, ${ }^{40}$ removing ECOSOC as a "buffer" between UNHCR and UNGA, and diminishing any authority that may have been inherent in this role. According to Paragraph 3 of the Statute, UNHCR still has a responsibility to follow policy advice provided by ECOSOC. In reality, ECOSOC resolutions do not tend to dictate policy that exclusively relates to refugees but instead, deals with matters that may affect refugees, such as violence against women $^{41}$ and issues that relate to a particular region or country. ${ }^{42}$

$34 \quad$ UNHCR Statute, para 3: «The High Commissioner shall follow policy directives given him by the General Assembly or the Economic and Social Council.».

35 UNHCR Statute, para 9: «The High Commissioner shall engage in such additional activities, including repatriation and resettlement, as the General Assembly may determine, within the limits of the resources placed at his disposal».

${ }_{36}$ C. Lewis, UNHCR and International Refugee Law: From treaty to innovation (Routledge, Abingdon, 2012) p. 52. An example of an UNGA resolution that provides policy guidance (Art 3), rather than creates additional activities for UNHCR (Art 9) is a request by the UNGA for UNHCR to improve international and burden sharing. Office of the High Commissioner for Refugees GA Res 61/137, UN GAOR $61^{\text {st }}$ sess, $81^{\text {st }}$ plen mtg, Agenda item 41, UN Doc A/RES/31/137 (19 Dec 2006).

37 V. Türk, "Freedom from fear: Refugees, the broader forced displacement context and the underlying international protection regime" in Vincent Chetail (ed), Globalization, Migration and Human Rights: International law under Review (Bruylant, Brussels, 2007) p. 481.

$38 \quad$ UNHCR Statute, para 11: «The High Commissioner shall be entitled to present his views before the General Assembly, the Economic and Social Council and their subsidiary bodies. The High Commissioner shall report annually to the General Assembly through the Economic and Social Council; his report shall be considered as a separate item on the agenda of the General Assembly».

39 Specialized agencies, i.e. International Monetary Fund (IMF), «are autonomous organizations working with the UN and each other through the coordinating machinery of the ECOSOC at the intergovernmental level, and through the Chief Executives Board for coordination (CEB) at the inter-secretariat level». See UN System Organizational Chart, October 2011, United Nations <www.un.org/en/aboutun/structure/org_chart.shtml> Accessed 17 October 2013.

$40 \quad$ C. Lewis, UNHCR and International Refugee Law: From treaty to innovation (Routledge, Abingdon, 2012) p. 13.

$41 \quad$ Strengthening crime prevention and criminal justice responses to violence against women 
To limit the parameters of the relationship between UNHCR and the UN as being restricted to the terms of UNHCR's mandate, however, is to underestimate the importance of functional autonomy to that relationship. UNHCR's position as a UN special programme means that it derives international legal personality that is compatible with its objectives and functions from the UN. ${ }^{43}$ An ability to act and speak autonomously is a constitutive element of legal personality ${ }^{44}$ and as a holder of international legal personality, regardless of its limitations, UNHCR exercises a separate will to the UN or member States by taking action that expresses its "corporate will" 45 rather than the "aggregate opinion" of member states. ${ }^{46}$ This action, which has been labelled "UNHCR Doctrine" ${ }^{47}$, describes UNHCR's "voice" on refugee issues, or the articulation of its views on such issues. UNHCR doctrine represents UNHCR's opinion on what refugee law is, what is should be and how it applies. Regardless of its form, which includes handbooks/manuals, policy and background papers, speeches, recommendations and commentaries, UNHCR doctrine, which has the common characteristic of being produced by the secretariat of the organisation, rather than by State representatives, is indicative of UNHCR's functional autonomy.

Functional autonomy need not be limited to autonomy as understood in relation to international legal personality. An organisation can also be considered functionally or "institutionally" autonomous based upon practice, functions and structure. UNHCR has been delegated a specific field of activity - international protection - over which it has complete responsibility. A specific field of activity is synonymous with "technical expertise", which has been considered evidence of institutional autonomy. ${ }^{48}$ Further, it has bureaucratic independence ${ }^{49}$ in the form of a self-sufficient, decision-making secretariat, its membership is differently constituted to the UN and States do not have the direct power to appoint its executive heads. ${ }^{50}$

ESC Res 2010/15, UN ESCOR, 45 ${ }^{\text {th }}$ plen mtg, UN Doc E/2010/15, 22 July 2010.

Economic and social repercussions of the Israeli occupation on the living conditions of the Palestinian people in the Occupied Palestinian Territory, including East Jerusalem, and the Arab population in the occupied Syrian Golan ESC Res 2010/31, UN ESCOR, $46^{\text {th }}$ plen mtg, UN Doc E/2010/31, 23 July 2010.

$43 \quad$ G. Verdirame, The UN and Human Rights: Who Guards the Guardians? (Cambridge University Press, Cambridge, 2011) p. 58.

44 J. d'Aspremont, "The multifaceted concept of autonomy of international organizations and international legal discourse" in Richard Collins and Nigel D White (eds), International Organizations and the Idea of Autonomy (Routledge, Abingdon, 2011) p. 63.

${ }_{45}$ N.D. White, 'Layers of autonomy in the UN system' in Richard Collins and Nigel D White (eds), International Organizations and the Idea of Autonomy (Routledge, Abingdon, 2011) p. 301.

46 J. Klabbers, An Introduction to International Institutional Law (Cambridge University Press, $2^{\text {nd }}$ ed, Cambridge, 2002) p. 12.

$47 \quad$ C. Lewis, UNHCR and International Refugee Law: From treaty to innovation (Routledge, Abingdon, 2012) p. 60.

48 M. Barnett and M. Finnemore, Rules for the World: International Organizations in Global Politics (Cornell University Press, Ithaca, 2004) p. 24.

${ }_{49}$ N.D. White, "Layers of autonomy in the UN system" in R. Collins and N. D. White (eds), International Organizations and the Idea of Autonomy (Routledge, Abingdon, 2011) p. 302.

50 C. Martini, "States' Control over New International Organization", 6 Global Jurist 
These observations are not made to argue that UNHCR is a completely autonomous organisation. The fact that it is a subsidiary organ is enough to counter such a suggestion. However, UNHCR has developed significant features of autonomy in a way that ensures that the UN's relationship with UNHCR is carried out according to what can be described as a "limited control model". "Limited control" means that the UNGA or ECOSOC do not generally act beyond the terms of UNHCR's Statute, leaving UNHCR with significant independence in decision-making, policy development and advice. The accountability obligations created by the relationship are limited to those specifically created by UNHCR's statute (Paragraphs 3, 9, and 11) and more generally, to account for the way it carries out its competence. Despite reference to UNHCR being «under the authority of the General Assembly» in Paragraph 1 of the Statute, the UN is not intended to exercise unbridled power over UNHCR - at least not when considered through legal accountability.

It has been observed that UNHCR, although «born with little autonomy and few prospects for expansion» has been «able to capitalize on world events and use its authority to greatly expand both the groups of people it assisted and the kinds of assistance it could give». ${ }^{51}$ This is perhaps, what ultimately drives the limited control model by the UN - recognition of the fundamental need for UNHCR to remain responsive to social and political change.

\subsection{UNHCR's Relationship with the UN: organisational accountability}

Like any organisation, much of what UNHCR does is dictated not by rules and legal obligations, but by the way it is designed and how its practice manifests. When UNHCR is understood through an open systems perspective, which is an organisational theory that focuses upon an organisation in relation to its context, ${ }^{52}$ a significant part of its practice becomes its interactions between internal and external stakeholders. These interactions, or institutional relationships, are driven by mutual accountability obligations that rely upon the structure, systems and processes $^{53}$ of the organisation, rather than its legal framework. Drawing upon the objective of organisational theory to understand how organisations function and relate to their environment, ${ }^{54}$ accountability in this context is understood as organisational accountability. When placed within the parameters of organisational accountability, the relationship between UNHCR and the UN remains vertical, creating obligations for both UNHCR and the UN that are based

Advances (2006) p. 24.

51 M. Barnett and M. Finnemore, Rules for the World: International Organizations in Global Politics (Cornell University Press, Ithaca, 2004) pp. 73, 118-20.

52 Open systems perspective has been described as «[...] systems of interdependent activities linking shifting coalitions of participants; the systems are embedded in [...] dependent on continuing exchanges with and constituted by $[\ldots]$ the environments in which they operate».

W. R. Scott, Organisations: Rational, Natural and Open Systems (Prentice Hall, New Jersey, 1992) p. 25.

53 A. Cunliffe, Organization Theory (SAGE Publication Ltd, Thousand Oaks, 2008) p. 4.

$54 \quad$ Ibid $3-4$. 
on UNHCR's position within the UN system, and which can conflict with the limited legal accountability obligations inherent to the relationship.

The hierarchical nature of the relationship between the UN and UNHCR reinforced by a number of services and programmes that specify and extend the kind of accountability obligations that are owed by UNHCR. The first of these services is the Office of Internal Oversight Services (OIOS), which was established in 1994 and is the UN's internal accountability mechanism. The OIOS operates as an independent office that assists the Secretary-General in the oversight of the UN through monitoring, internal audit, inspection, evaluation and investigation. ${ }^{55}$ In particular, it ensures agency compliance with resolutions, rules and policy and seeks to prevent «fraud, waste, abuse, malfeasance and mismanagement». ${ }^{56}$ The OIOS creates obligations for UNHCR by putting procedures in place that ensure that UNHCR, along with other bodies within the UN system, is accountable for the efficient and effective delivery of the "organisation's activities". Further, it ensures that it is answerable, and accountable, for misconduct. The OIOS has conducted two investigations into allegations of UNHCR misconduct. The first, undertaken in 2002, investigated allegations of sexual exploitation of refugees by aid workers within refugee camps in West Africa. ${ }^{57}$ The second involved the establishment of a specialised task force to investigate allegations of corruption at the UNHCR office in Nairobi. ${ }^{58}$ Although the OIOS was unable to verify the alleged incidents that precipitated the investigation into sexual exploitation, it found that sexual exploitation of refugees was "real". The corruption allegations however, were verified, with the task force finding that refugees were being asked to pay money for positive status determination and a number of people, including UNHCR staff and Kenyan police officers, were arrested. The fact that it was UNHCR itself who requested that OIOS investigate the allegations in both cases does not detract from the fact that the OIOS ensures that UNHCR is accountable to the higher levels of the UN (i.e. the Secretary-General) for the actions of its staff and partners. The final paragraph of the report into the investigation of corruption in Nairobi contains comments made by UNHCR acknowledging as such.

The situation that led to the need for this investigation is indeed regrettable, but UNHCR has been able to learn and implement many lessons from the investigation. As a result of the experience in Kenya, UNHCR will in the coming months become a much more accountable organization, management and

\footnotetext{
55 Office of Internal Oversight Services <www.un.org/Depts/oios/>. Accessed 30 January 2013. 56 Ibid.

57 The Secretary-General, Investigation into Sexual Exploitation of Refugees by Aid Workers in West Africa: Report of the Secretary-General on the Activities of the Office of Internal Oversight Services, Summary, UN Doc. A/57/465 (Oct. 11, 2002).

${ }_{58} \quad$ OIOS, Investigation Into Allegations Of Refugee Smuggling At The Nairobi Branch Office Of The Office Of The United Nations High Commissioner For Refugees, U.N. Doc A/56/733, December 21, 2001.
} 
performance will be strengthened and the oversight and investigation capacity will be improved ${ }^{59}$.

When UNHCR comments that it will become "a much more accountable organization" it is not just referring to accountability to refugees, it acknowledging its accountability within the UN system.

Other relevant programmes or services are those that have been developed internally or in collaboration with partners to create accountability obligations that are specific to the UN's functions and/or to particular position holders within the UN. First, the UN Security Management System (UNSMS), whose mission it is «to enable the conduct of United Nations activities while ensuring the safety, security and well-being of personnel and the security of United Nations premises and assets», ${ }^{60}$ creates a relationship between «Executive Heads of the United Nations Agencies, Funds and Programmes and the Secretary-General» to ensure «that the goal of the UNSMS is met within their respective organizations». ${ }^{61}$ The UNSMS Policy Manual expressly states that Executive Heads are responsible and accountable to the Secretary-General and that in recognizing the coordinating role and authority of the Secretary-General in matters related to the safety and security of UN personnel, they commit themselves to ensuring that the goal of the UNSMS is met. ${ }^{62}$

Second, the 2005 Inter-Agency Standing Committee Humanitarian Reform Initiatives (IASC Initiatives) create a relationship between UNHCR and the UN where the accountability obligations are specific to a particular area of the UN's functions (i.e. humanitarian aid) and the immediate recipients of accountability are high-level office holders within the UN (the Emergency Relief Coordinator and Humanitarian Coordinators). Under the IASC "cluster" model, a cluster lead (UNHCR) is directly accountable to the Emergency Relief Coordinator for: ensuring system-wide preparedness and technical capacity to respond to humanitarian emergencies; ensuring greater predictability; and more effective inter-agency responses in their particular sectors or areas of activity. ${ }^{63}$ At a country level, UNHCR is accountable to the Humanitarian Coordinator for ensuring, to the extent possible, the establishment of adequate coordination mechanisms for the sector or area of activity concerned; adequate preparedness; and adequate strategic planning for an effective operational response. ${ }^{64}$

Not all of UNHCR's organisational accountability obligations are so easily identifiable, however. First, there is an "unspoken authority" implicit to hierarchical accountability that can manifest in the way that the removal of senior officials is dealt with. Whilst the appointment of senior officials within the UN

\footnotetext{
$59 \quad$ Ibid (emphasis added).

60 UNSMS, Framework for Accountability for the United Nations Security Management System, United Nations Department of Safety and Security ('Security Framework') (February 2011) 1 .

$61 \quad$ Security Framework, 3.

62 Security Framework, 3.

63 Inter-Agency Standing Committee (IASC) Guidance Note on Using the Cluster Approach to Strengthen Humanitarian Response ('IASC Guidance Note') (24 November 2006) 9.

$64 \quad$ IASC Guidance Note 10.
} 
may be a transparent process that is carried out according to formal and accepted procedures, the removal of those officials from office can be far more opaque. The election and re-election of the High Commissioner for Refugees is made by the UNGA on the proposal of the UN Secretary-General and given formality and transparency in the form of a UNGA decision. ${ }^{65}$ However, in circumstances where a High Commissioner has vacated the office prior to the completion of his or her term, he or she has generally resigned.

In 1989, the then High Commissioner for Refugees Jean-Pierre Hocke resigned because of an accusation that he had used Danish contributions to «a fund set up by Nordic countries for refugee education to pay for entertainment and first-class air travel, sometimes aboard the Concorde, for himself and his wife». ${ }^{66}$ A number of years later in 2005, a second scandal caused the resignation of another High Commissioner, Ruud Lubbers, who was accused of sexually harassing a female employee. Although both Commissioner's resigned rather than being officially removed from office, the extent to which their decisions were free from political pressure, particularly from the UN Secretary-General, merits questioning. Despite Mr Hocke maintaining that he «did not feel to have been pressured» in making his decision, ${ }^{67}$ some newspapers at the time reported that the then UN SecretaryGeneral, Javier Perez de Cuellar, told Hocke that he could not remain at his post. ${ }^{68}$ At the news conference announcing his resignation, Hocke read out a letter which said, amongst other things, that his resignation did «not reflect any sentiment of culpability on my part concerning any of my doings» and mentioned the «destructive intentions of some people here and elsewhere». ${ }^{69}$ Lubbers on the other hand, spoke directly about the pressure placed on him by Koffi Annan, the UN Secretary-General at the time, to resign. Although the day before the announcement of his resignation, Lubbers had said that Annan had not asked him to resign, in his resignation letter he said that Annan had given him two choices resign or face suspension and charges of breaking UN rules. Maintaining his innocence, Lubbers said, «To be frank, and despite all my loyalty, insult has now been added to injury and therefore I resign as High Commissioner». ${ }^{70}$

Resignation is a useful public relations tactic, a way to maximize damage control in difficult circumstances. Although presented as a freely made decision, it is likely that both Hocke and Lubbers were placed in positions where they were left with little choice but to resign. Lubbers' veiled accusation and Hocke's denial of culpability and counter-attack on persons unknown is testament to that. The UN Secretary-General is highly influential in the election of a candidate to the office of the High Commissioner and he or she is the ultimate authority in the removal, or resignation of the Commissioner from office. Whether transparent or

\footnotetext{
65 Election of Sadako Ogata as High Commissioner for Refugees - Official Records of the General Assembly, Forty-fifth Session, Supplement No. 49 (A/45/49)

66 P. Lewis, "U.N. Refugee Chief Quits Over His Use of Funds" The New York Times October 27, 1989.

67 "Hocke Says Resignation Was His Decision' Associated Press" Oct 27, 1989.

68 "UN Refugee Commissioner Resigns" Anchorage Daily News 27 October 1989, A9.

69 "Hocke Says Resignation Was His Decision" Associated Press, Oct 27, 1989.

70 "U.N. refugee chief Lubbers resigns over sex allegations" Associated Press, 20 February

2005.
} 
"unspoken", the authority inherent in the ability of the Secretary-General to influence the resignation of a High Commissioner without the need for more formal "removal" procedures solidifies the relationship between the UN and UNHCR as traditionally hierarchical and one that is based upon a model of vertical accountability.

A second example of "unspoken authority" is where the UN Secretary-General has made decisions to override action taken by High Commissioners, which arguably exhibits authority that conflicts with the limited control model inherent in the legal accountability obligations owed by UNHCR to the UN. The reprimand of Sadako Ogata, High Commissioner for Refugees, by Boutros Boutros-Ghali, UN Secretary-General in February of 1993 was a clear indication that in certain circumstances, the Secretary-General will override a High Commissioner's decision. It is arguable that such action has no basis in the terms of UNHCR's Statute or in its legal position as a subsidiary organ of the UN.

After High Commissioner Ogata had ordered the cessation of aid to some parts of Yugoslavia due to militants impeding its delivery, Boutros-Ghali publicly rebuked her and overturned her decision by ordering UNHCR to resume humanitarian assistance to the area. ${ }^{71}$ The UN Secretary-General is given no specific authority to make such an order outside of the authority the UNGA and ECOSOC are given to issue policy directives to the High Commissioner ${ }^{72}$ or for the UNGA to determine additional activities. ${ }^{73}$ As mentioned above, the phrase «under the authority of the General Assembly» means that UNHCR acts at the direction of the UNGA and not the UN Secretary-General ${ }^{74}$ or any other principal organ of the UN such as the UN Security Council. If the authority to act in such a manner does not find support in the constitution of UNHCR, might it be justified by UNHCR's position as a subsidiary organ of the UN? It is arguable that Boutros-Ghali's actions also went beyond that expected of a principal organ. In its report on the accountability of IOs, the ILA considered that the power of a parent organisation extended to the overruling of a decision of a subsidiary organ if that decision was contrary to applicable legal rules. ${ }^{75}$ It is difficult to see how a decision made about humanitarian aid delivery could be so defined. The actions of the UN Secretary-General were extraordinary, not only because they exposed political conflicts over UN programme management ${ }^{76}$ but also because they were a clear indication that the authority of the UN (in the guise of the UN SecretaryGeneral) over subsidiary organs has the potential to extend beyond legal rules into "interference" with policy decisions made at the most senior levels.

The layers of accountability created by institutional factors in the context of hierarchical relationships will generally have the effect of expanding the

\footnotetext{
71 "U.N Chief rebukes Aid Chief, restores relief", The Times February 20, 1993, 14A.

$72 \quad$ UNHCR Statute, para 3.

$73 \quad$ Ibid para 9.

74 Guy Goodwin-Gill and Jane McAdam, The Refugee in International Law (Oxford University Press, 3rd ed, Oxford 2007) p. 429.

$75 \quad$ ILA Report, p. 6.

76 Boutros-Ghali is quoted as saying 'I am supposed to direct this operation'. "U.N Chief rebukes Aid Chief, restores relief”, The Times, February 20, 1993, 14A.
} 
accountability obligations owed by the subordinate to the principal. However, where that relationship is inter-institutional and the subordinate party is a subsidiary of the principal, accountability must be reciprocal. Reciprocal or "reverse" accountability means that, despite the centrality of supervision and control in the role of the principal, the principal also owes accountability obligations to the subsidiary. Under the heading "Supervision and Control" the ILA report makes the following relevant recommendations:

1) IO-s remain fully accountable for the actions and omissions of subsidiary organs;

2) Parent organs have a duty to exercise a degree of control and supervision over subsidiary organs which corresponds to the functional autonomy granted; [...]

5) An organ of an IO that has delegated the exercise of any of its powers or functions remains fully accountable for the way in which the power or function is being exercised $[\ldots] .^{77}$

The ILA's position that an IO is «fully accountable for the actions and omissions of subsidiary organs» and for the way in which its delegated powers or functions are exercised places important controls on the potential for the kind of arbitrary exercise of authority that may occur within hierarchical relationships. The ILA's view of inter-organisational accountability reflects a strong compulsion against tyrannical, unbridled authority within IO governance and has the effect of reversing the vertical flow of accountability within the UN/UNHCR relationship by turning UNHCR into a recipient of accountability.

UNHCR's place in the UN system informs a more far-reaching concept of accountability than its legal status as a subsidiary body implies. When the hierarchical aspect of the relationship between a subsidiary and principal organ manifests within a practical institutional context, accountability not only subsumes existing organisational accountability mechanisms, it receives the "unspoken" elements of authority that are inherent in hierarchical relationships. The institutional design of UNHCR expands the relationship between UNHCR and the UN by providing for accountability obligations that are additional to those created by UNHCR's Statute. Whilst most of these obligations increase the accountability owed by UNHCR, some create an accountability obligation for the $\mathrm{UN}$ in respect of the actions of UNHCR.

The complexities and intersections of UNHCR's relationship with the UN are represented in the following conceptual model, which maps the accountability elements of the relationship between UNHCR and the UN.

Figure 1. UNHCR and the UN: Accountability Obligations

$77 \quad$ ILA Report, p. 1. 


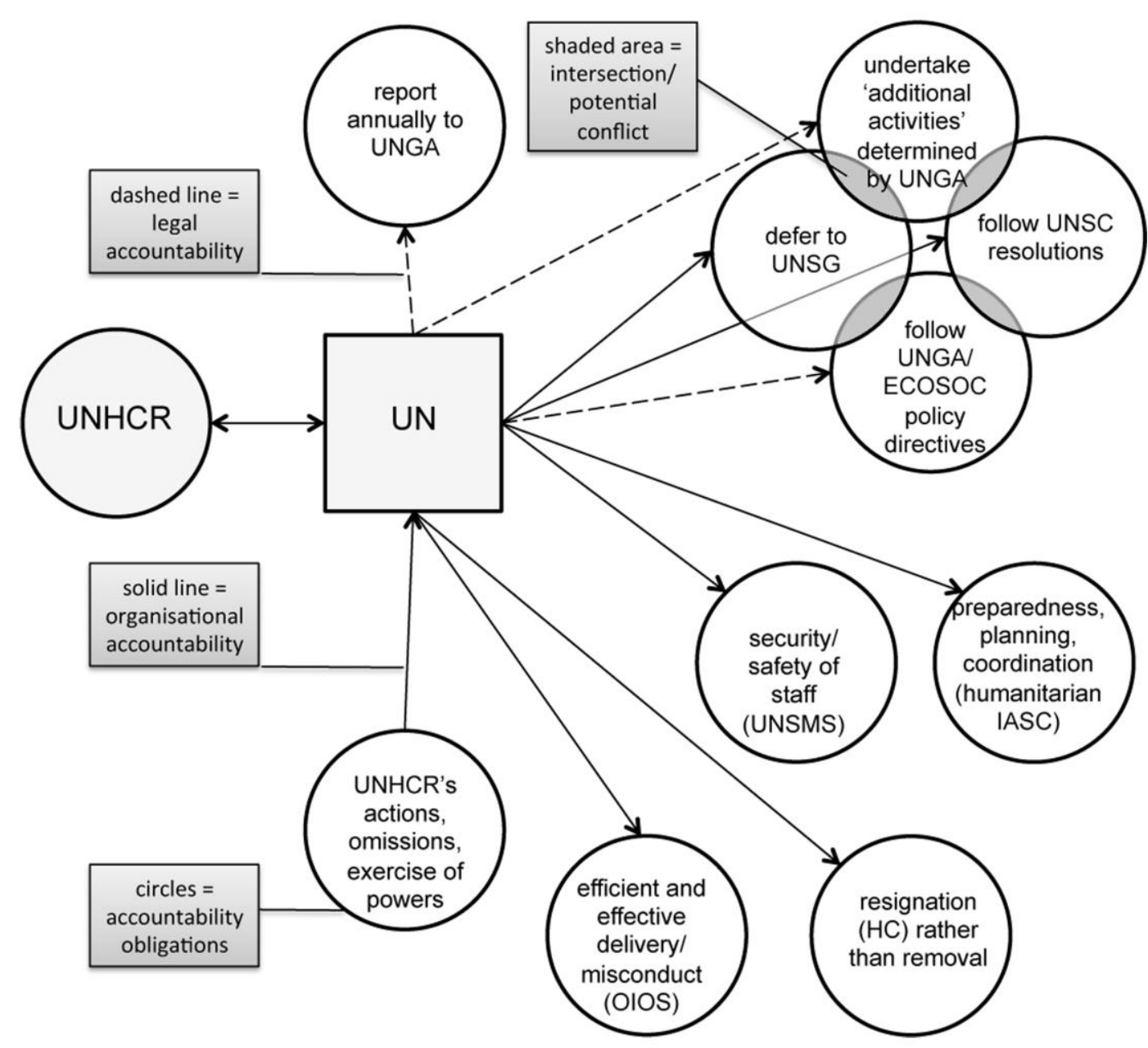

The model identifies ten accountability obligations (represented by circles) that are created by the relationship between UNHCR and the UN.

Three of these obligations, "report annually to UNGA", "undertake additional activities determined by UNGA" and "follow UNGA/ECOSOC policy directives" are characterised through legal accountability (represented by dashed arrows).

The remaining six obligations are products of organisational accountability (represented by solid arrows), five of which expand the authority of the UN and the accountability obligations of UNHCR. One organisational accountability obligation, "UNHCR's actions, omissions, exercise of powers/function" creates a reverse accountability obligation for the UN to take responsibility for the actions of UNHCR.

Four of UNHCR's accountability obligations intersect and potentially conflict with each other. UNHCR's legal accountability to "undertake additional activities determined by UNGA" and "follow UNGA/ECOSOC policy directives" intersect with its obligations to "defer to UNSG" and "follow UNSC resolutions" because 
the latter require it to respond to authority within the UN in a way that is beyond what is contemplated by UNHCR's Statute and which arguably undermines its independence.

\section{Conclusion}

The complexity of the inter-institutional relationship between UNHCR and the $\mathrm{UN}$ renders attempts to draw bright lines around its nature futile. Its legal scope is determined by UNHCR's Statute and the implications of its position as a subsidiary organ of the UN, but the institutionally hierarchical nature of the relationship introduces less stable elements that expand, contract and occasionally undermine its legal or constitutional parameters. In addition, UNHCR's institutional autonomy diminishes the practical authority that the UNGA holds as principal organ. Counterintuitive as it may seem, the relationship is typical of inter-institutional relationships in the global space in the sense that their commonality is diversity, and to understand those relationships is to appreciate and accept plurality.

Plurality is nowhere more relevant than in regards to global accountability, an issue that occupies a significant portion of critical attention to global governance. If there are to be "solutions" to the accountability issues created by a context where the bounds on governance are weak and divergent, accountability must be understood in relation to that context and not according to traditional notions that are an uneasy fit for the global space. If accountability is understood in relation to relationships, not only are the unique accountability obligations of a global body revealed, the reasons why a body fails to be accountable becomes apparent. Without this fundamental insight, accountability mechanisms risk becoming aspirational tools that "say the right thing" yet remain ineffectual because of their failure to understand and respond to their subject. 